\title{
What drives European port traffic? The role of competition
}

\author{
Xavier Fageda \\ Economic Policy Department, \\ University of Barcelona, \\ Av. Diagonal, 690; 08034, Barcelona, Spain \\ Email:xfageda@ub.edu \\ Marta Gonzalez-Aregall* \\ Department of Business Administration, \\ School of Business, Economics and Law, \\ University of Gothenburg, \\ Vasagatan 1, 41124, Gothenburg, Sweden \\ Email: marta.gonzalez-aregall@gu.se
}

\begin{abstract}
This article examines the determinants of traffic in European ports in 2010 by estimating a generalized linear model with a gamma distribution. Controlling for various economic and geographic attributes of the regions in which the ports are located, we analyze the impact of the competition scenarios that the respective port authorities face. We include a range of explanatory factors of port traffic including the share of transshipment traffic, the competition within a terminal, the volume of traffic from neighboring ports, the level of connectivity with other transportation modes and the port's model of governance. The main findings indicate that a bureaucratic model of governance can harm traffic levels, while traffic from neighboring ports and better rail facilities can all serve to boost traffic. Finally, we do not find evidence that competition within the port can affect traffic positively.
\end{abstract}

Keywords: ports, competition, governance, traffic, gamma distribution 


\section{INTRODUCTION}

In recent years, international maritime transportation has played a critical role in the strengthening of the relationship between trade and economic development, with such factors as the container revolution and burgeoning trade flows ensuring that ports have become a vital element in economic growth. Several empirical studies have examined the economic impact of port traffic on the European (Bottasso et al., 2013), Italian (Ferrari et al., 2010) and Spanish regions (Fageda and Gonzalez-Aregall, 2015), concluding that port throughput has a positive effect on employment. Similarly, Shan et al. (2014) reported a positive relationship between per capita GDP and port traffic in China. In addition, Arbués et al. (2015) found that seaport investment in Spain can have positive effects spilling over into neighboring regions.

Europe, because of its highly developed economy and large population, is one of the world's main trading regions (Stopford, 2009), as illustrated by the volume of cargo flows handled on its trade routes. Thus, the transatlantic route between America and Europe shifts a stable traffic of six million full TEUs ${ }^{1}$ per year and the Asia and Europe route moves 20 million full TEUs per year (UNCTAD, 2013). Against this backdrop of globalized markets, the world's ports are subject to increasingly intense competition as they seek to attract more traffic from global competitors as well as from local ports in overlapping hinterlands (Xiao et al., 2012). A number of studies claim that this increased competition is closely related to processes of containerization and port devolution ${ }^{2}$ (Yuen et al, 2012; Zhang, 2008). For example, in the gateway region of the Rhine-Scheldt Delta, Notteboom (2009) observed that the region's largest ports were substitutes for each other and that its smaller ports were complements of these large load centers.

In this paper, we examine the factors that account for the volume of traffic handled by Europe's ports by means of an econometric analysis. Controlling for the economic and geographic attributes of the regions in which the ports are located, we analyze the influence of the competition scenarios that port authorities face. Indeed, greater competition may enhance efficiency (Garcia-Alonso and Martin-Bofarull, 2007; Figueiredo De Oliveira and Cariou, 2015), promote a port's attractiveness ( $\mathrm{Ng}, 2006)$ and influence investments and prices (Van Reeven, 2010, Xiao et al., 2012). In short, a more competitive scenario can have the effect of boosting port traffic. In contrast, competition might mean some ports

\footnotetext{
1 TEUs: Twenty-foot Equivalent Units.

2 The OECD (2008) report explains that containerization allows ports in the same region to become substitutes, exposing them to more competition from other ports, and that the devolution of port management results in ports adopting a more commercial approach, which intensifies competition.
} 
suffer reductions in traffic at the expense of other, more efficient, ports. Thus, traffic may well be diverted from small to large ports that are connected to extensive hinterland networks (Notteboom, 2010). Additionally, such factors as the level of connectivity with surface transportation modes and the degree of inland congestion can shift traffic to more efficient ports (Zhang, 2008).

The primary objective of this article is to determine whether a more competitive scenario benefits port traffic in the European Union. The study focuses on total container traffic as opposed to total traffic, since in this way we can take into account competition not only from the local market but also from other regions. Moreover, the availability of data for all port authorities and the homogeneous characteristics of containers allow us to compare port traffic records.

While traffic that ports are able to generate may be strongly affected by the competition that they must afford, no previous paper has analyzed the impact of competition on port traffic by performing an econometric analysis. Hence, our paper contributes to the literature by reporting an analysis of the determinants of European port traffic using a multivariate equation. Previous studies have analyzed the impact of a range of specific factors on port efficiency. For example, Garcia-Alonso and Martin-Bofarull, (2007) examined the effect of improvements in efficiency in attracting more traffic, while Figueiredo De Oliveira and Cariou (2015) investigated the impact of inter-port competition on efficiency. Furthermore, several studies have analyzed the impact of privatization (eg; Cheon et al, 2010; Cullinane et al, 2002; Czerny et al., 2014; Liu, 1995; Tongzon and Heng, 2005) and reforms towards more autonomy of port authorities (eg; Barros and Athanassious, 2004; Estache et al., 2002; González and Trujillo, 2008) on port efficiency. ${ }^{3}$ Other studies have examined the effect of competition on port traffic but have tended to focus on one port region and to undertake analyses of variance, reveled preference indicators or time-series analysis (Castillo-Manzano et al., 2008; Ng, 2006; Notteboom, 2009).

This paper uses econometric techniques to estimate a multivariate equation that simultaneously considers port attributes, surface transport connectivity and governance variables of a large sample of European ports. Although previous studies have evaluated Europe's port system (Notteboom, 2010), none have examined simultaneously the

\footnotetext{
${ }^{3}$ González and Trujillo (2009) provide a detailed review of empirical studies about port efficiency.
} 
influence of such a broad range of factors on port traffic. We find that competition between ports may spur traffic, while competition within a port may not be so effective in increasing port traffic. Indeed, we find evidence that a more intense competition between ports may boost traffic as suggest the results for the variables that identify the traffic of nearby ports and the governance model. Furthermore, we do not find clear evidence that competition within the port increases traffic as ports with a terminal managed by a shipping line have more traffic. In this regard, we also find that ports with a greater share of transshipment traffic have more traffic. Hub ports may be subject to a more intense competition from other ports but they tend to be dominated by one shipping line. Finally, we also find that those ports connected with rail facilities that can move trains of more than 700 meters length are able to generate more traffic.

The rest of the paper is organized as follows: Section 2 outlines the main features of the European port authorities included in our sample focusing especially on those factors that may determine the competition scenario in which they operate; Section 3 describes the empirical model used and provides a justification of the explanatory variables selected. Section 4 addresses some econometric issues and explains the results of the estimates. Finally, the last section is devoted to summarizing the main findings and discussing the policy implications.

\section{SAMPLE OF EUROPEAN PORTS}

This section provides an exploratory analysis of the factors explaining the intensity of port competition among European port authorities considered in our analysis. Our database draws on the Containerization Yearbook for 2012. From the World Container Port Traffic League (totaling 365 port authorities), we consider 92 European Port authorities for which we have data available. Our sample permits us to analyze all the largest European port authorities and most medium and small port authorities. This sample represents a high percentage of total port traffic in Europe. ${ }^{4}$

Thus, we can take advantage of a large cross-section in our empirical analysis. A limitation of our data is that they refer to just one year. While extending our sample to create a panel would be preferable, we still think that our analysis is valuable. Note that several explanatory variables are time invariant. Furthermore, in the context of our analysis,

${ }^{4}$ See table A1 in the Annex for a list of all port authorities contained in our database, with data about traffic and governance characteristics. 
the between variation of the data (variation across ports) should be much more relevant than the within variation of the data (variation over time of each port).

An increase in maritime freight traffic has led to a rise in long-distance containerized trade. A difficulty in establishing direct shipping connections induced the emergence of intermediate transshipment ports (ITF, 2009). According to Portopia (2012), large hub ports are those with more than 2 million TEUs and with a transshipment incidence of greater than $50 \%$ of their total TEU throughput. ${ }^{5}$ Note that one terminal (at least) of these large hub ports is usually controlled by a single shipping company.

Consequently, we observed that these transshipment ports are subject to more competition with other ports but not within the port itself. To illustrate, Bremen is a transshipment port located in the North of Europe and has a terminal controlled by MSC and Maersk. Furthermore, the transshipment port of Marsaxlokk is located in the Island of Malta and it has a terminal managed by CMA-CGM. Note here that the aim of this analysis is to measure the dominance of pure shipping lines. For example, APM Terminal is a subsidiary of Maersk but in our analysis it is considered a Terminal Operator according to the classification of Notteboom and Rodrigue (2012). ${ }^{6}$

Undoubtedly, this increase in maritime freight traffic has affected local port competition and hinterland connections. In this regard, the potential hinterland of a port can be defined as the area that can be reached in the least amount of time while incurring the lowest cost (Wilmsmeier et al., 2011). While overlapping hinterlands can occur in contiguous port market areas (Van Klink and Van den Berg, 1998), this area is essential for port competition (Wan et al., 2013) and has an impact on port growth (Zhang, 2008). Thus, ports with rail facilities within a terminal may expand their hinterland. Furthermore, Turner et al. (2004) provide evidence about the role of the rail industry as a critical determinant of port infrastructure productivity. In this regard, port terminals with suitable rail facilities are fundamentally located in the North compared to a lack of availability of rail facilitates in the Southern ports of Europe. ${ }^{7}$ Castillo-Manzano et al (2013) found that the poor intermodal port-to-rail connections in Spain has damaged the competitiveness of ports.

\footnotetext{
In our analysis ports with these characteristics are Bremen (Germany), Gioia Tauro (Italy), Algeciras (Spain) and Marsaxlokk (Malta). We do not have available data on transshipment traffic for all ports in our sample to identify smaller hubs.

${ }^{6}$ According to the authors, almost $75 \%$ of the total European Container throughput in 2008 was handled by the top five terminal operators: PSA, APM Terminals, HPH, DP World and Eurogate.

7 Rotterdam (Netherlands), Antwerp (Belgium), Hamburg (Germany), Bremen (Germany), Zeebrugge (Belgium), Le Havre (France), Genoa (Italy), Duisburg (Germany), Marseilles (France), Strasbourg (France), Gavle (Sweden), Bristol (UK) and Amsterdam (Netherlands).
} 
Similarly, the amount of port traffic that is operated in the same region can affect the degree of competition with nearby ports. As can be seen in Figure 1, the three major ports move more than 5 million TEUs and are located in Northern Europe. Port authorities in the range of 1 to 5 million TEUs are primarily located in Germany, France, UK, Spain and Belgium. Finally, the majority of port authorities are smaller, containing less than 0.5 Million TEUs. From figure 1, it can be concluded that the majority of regions in the Southern Europe have smaller, local ports while the most concentrated traffic throughput and the largest ports are based in the North of Europe regardless of its size and population.

\section{Figure 1: Traffic in European ports}

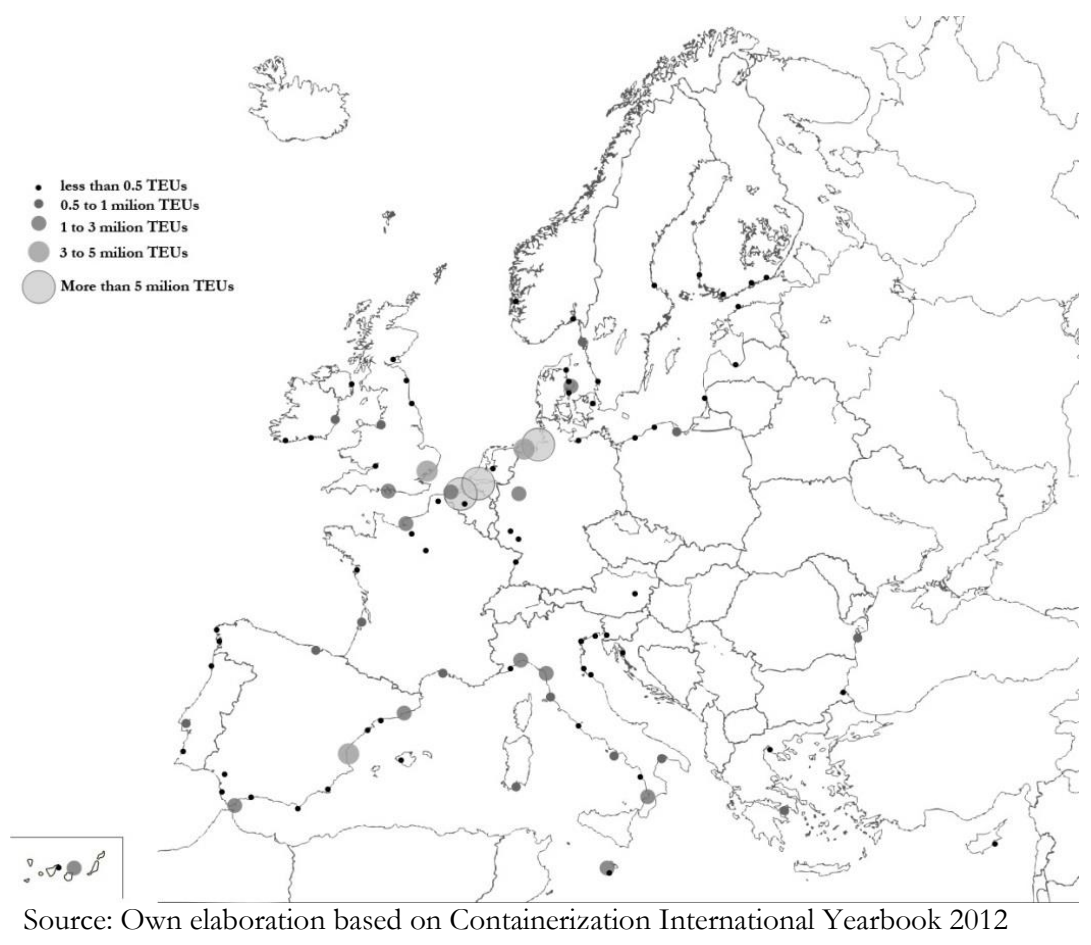

The complexity and diversity of Europe's port authorities has had a marked influence on competition. Notteboom and Verhoeven (2010) and Notteboom et al. (2012) perceive the diversity of the port authorities in terms of the involvement of private operators. Likewise, Wang and Cullinane (2006) indicate that different systems of port governance in Europe might be a key determinant of container terminal efficiency. ${ }^{8}$

The development of the European Union has seen the establishment of a single market place typified by economic integration and intense competition. ${ }^{9}$ However, while the

\footnotetext{
8 Trujillo and Tovar (2007) examined the economic efficiency of the European port industry.

${ }^{9}$ For an analysis of organization and regulation theory and port industry in Europe see Tovar et al. (2004).
} 
European Commission has taken steps to set up a common European port policy (Verhoeven, 2009), the decision-making process of the port agents has yet to be harmonized (Pallis, 2007).

Since the eighties, almost all port authorities have undergone a process of devolution with greater private involvement (Brooks, 2004) and different governance strategies. ${ }^{10}$ So as to analyze the effect of port governance models on port traffic competition, we based on three different viewpoints: regulation, finance and ownership.

First, few studies have evaluated regulation needs in relation to port traffic. According to Trujillo and Tovar (2012), competition is an economic factor that has an influence on port regulation, which in turn affects port traffic. Likewise, some studies have taken into account the effect of port pricing regulation. Thus, theoretical studies tend to associate investment in port capacity and hinterland congestion with port prices (De Borger et al., 2008) and a shipping line's choice of port (Bae et al., 2013). Whereas, the empirical analysis conducted by Fageda and Gonzalez-Aregall (2014) concluded that the strict regulation of port charges in Spain influenced the volume of port traffic and mitigated price competition.

Secondly, an analysis of port finance systems ${ }^{11}$ shows that typically governments use public resources to subsidize basic port infrastructure. Yet, the growth of the private sector has led to a debate regarding the introduction of limits on port investments (World Bank, 2007). However, no previous study has examined the relationship between port financial management and port traffic. To our knowledge, only the study of Castillo-Manzano et al. (2010) provide evidence about the positive effect on port traffic of the successive reforms in Spain that have given more autonomy to port authorities in the management and organization of their activities.

Finally, more studies can be found on the effects of privatization on port efficiency. Privatization may have a positive effect on port efficiency, technical progress and national welfare (Cheon et al, 2010; Cullinane et al., 2002; Czerny et al., 2014). However, Tongzon and Heng (2005) conclude that the best option for port efficiency is to limit private sector participation and Liu (1995) do not find differences between public and private British ports. However, to the best of our knowledge, no previous studies have analyzed the relationship between port governance systems and port traffic.

\footnotetext{
${ }^{10}$ For a port governance model (Service Port, Tool Port, Landlord Port, Private Port) see World Bank (2007).

${ }^{11}$ For a detailed analysis of port finance systems see World Bank (2007).
} 
Drawing on a number of research studies (the Espo Fact Finding Report, 2010; Verhoeven and Vanoutride, 2012; ISL report, 2006 and OECD Policy Round Tables, 2011; World Bank, 2007), with the goal of determining a simple homogeneous structure for Europe's port system, we classify them in three categories: market, hybrid and bureaucratic. $^{12}$

The first category - market port systems - includes those port authorities with their own management body operated by a private firm, with its own financial resources and a regulatory framework based on free market prices. Port authorities with these characteristics can be found above all in the United Kingdom.

The second category - hybrid port systems - includes all port authorities with an autonomous individual management run by the regional or local government. These port authorities may be recipients of public aid, including subsidies financing their infrastructure, while their regulatory framework is based on free market prices or regulation imposed by the local government. Examples of the hybrid port system can be found in Amsterdam, Antwerp and Rotterdam.

The third category - bureaucratic port systems - includes port authorities with individual management run by the central government and public financial resources (public subsidies). These port authorities operate strict regulatory frameworks where prices are established by the central government. Examples can be found in France, Spain and Italy. Figure 2 shows the location of the different European port systems in our analysis.

12 Espo Fact Finding Report (2010) and Verhoeven and Vanoutride (2012) classify port authorities in three regions: Hanse (North), Latin (South) and Anglo-Saxon (United Kingdom). They conclude that differences exist in terms of ownership and financial autonomy (port authorities being more limited in the south) and between small and large ports, with the latter presenting more transparent systems of management. 


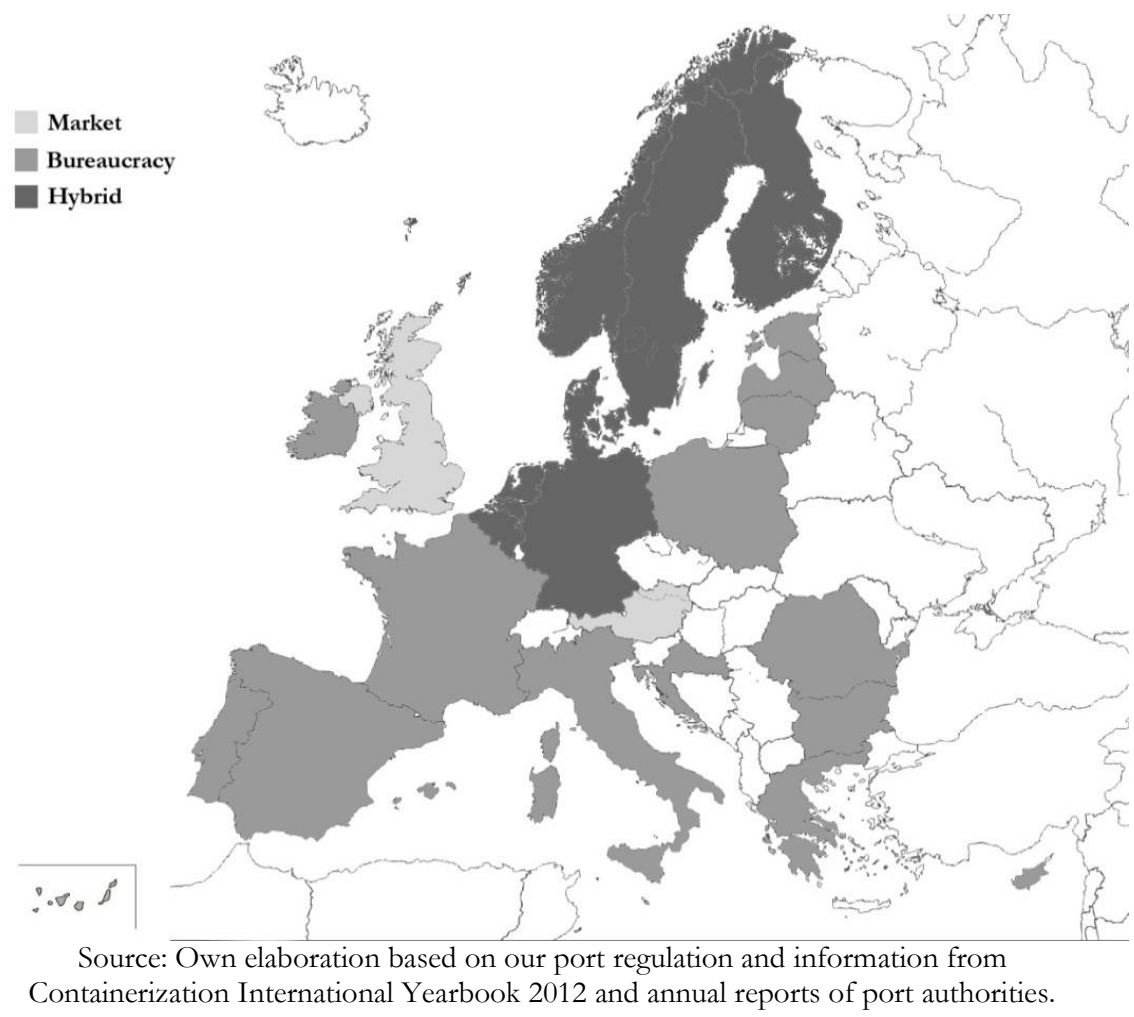

As can be seen, the dominant port system in Southern Europe (grey color) is the bureaucratic model, characterized by a strict regulation and less price flexibility. In case that competition between ports spur traffic, we may expect that ports under this system absorb less traffic than ports located in Northern Europe (black color) dominated by the hybrid model. Likewise, we expect greater traffic volumes in ports operating a market system (light grey) which are the ports located in the United Kingdom and Austria.

\section{THE EMPIRICAL MODEL}

In this section we develop an empirical model to estimate the factors that influenced container traffic in European ports during 2010. First, we consider a number of control factors, including, the economic and geographic attributes of the region in which the port authorities are located. Second, we consider such port attributes as the share of transshipment traffic, competition within terminals and the volume of traffic at neighboring ports. Third, we include variables related to surface transportation modes. Finally, we take into account the different port governance models operated by the port 
authorities. In short, these factors can affect port competition between other ports but also within the own port authority.

We estimate a cross-sectional equation in which the dependent variable is the amount of container port traffic handled by the European port authority $i$ during 2010 . The equation to be estimated is as follows:

$$
\begin{aligned}
\text { Traffi }_{i t} & =\beta_{0}+\beta_{1} \text { GDP }_{i t-1}+\beta_{2} \text { long }_{i}+\beta_{3} \text { latit }_{i}+\beta_{4} \text { inland }_{i}+\beta_{5} \text { island }_{i}+\beta_{6} \text { hub }_{i t}+\beta_{7} \text { no__multiuser }_{i t} \\
& +\beta_{8} \text { traffic_nearby }_{-} \text {ports }_{i t}+\beta_{9} \text { motorway }_{i t}+\beta_{10} \text { railfacility }_{i t}+\beta_{11} \text { hybrid }_{i t}+\beta_{12} \text { bureaucrac }_{i t}+\varepsilon_{t}
\end{aligned}
$$

Table 1 shows the variables used in the empirical analysis, the sources of information and the descriptive statistics. We group the variables into four categories: Economic and geographic attributes of the region, port attributes, surface transportation and port governance models.

\begin{tabular}{|c|c|c|c|c|c|c|c|}
\hline & Variable & Description & Source & Mean & $\begin{array}{l}\text { Standard } \\
\text { Deviation }\end{array}$ & $\begin{array}{l}\text { Minimum } \\
\text { Value }\end{array}$ & $\begin{array}{l}\text { Maximum } \\
\text { value }\end{array}$ \\
\hline $\begin{array}{l}\text { Dependent } \\
\text { Variable }\end{array}$ & TRAFFIC & $\begin{array}{l}\text { Total amount of } \\
\text { container traffic } \\
\text { in } 2010\end{array}$ & $\begin{array}{l}\text { Containerization } \\
\text { International } \\
\text { Yearbook } 2012\end{array}$ & 898844.2 & 1792942 & 41500 & $1.11 \mathrm{e}+07$ \\
\hline \multirow{6}{*}{$\begin{array}{l}\text { Economic and } \\
\text { geographic } \\
\text { attributes of } \\
\text { the region }\end{array}$} & $\mathrm{GDP}_{\mathrm{t}-1}$ & $\begin{array}{l}\text { Gross domestic } \\
\text { product in } 2009 \\
\text { (current market } \\
\text { prices/euro per } \\
\text { inhabitant at } \\
\text { NUTS 2) }\end{array}$ & $\begin{array}{l}\text { Eurostat } \\
\text { database }\end{array}$ & 70257.53 & 69235.69 & 3703 & 558579 \\
\hline & LONGITUDE & $\begin{array}{c}\text { In the East } \\
\text { (higher values) } \\
\text { or in the West } \\
\text { (lower values) }\end{array}$ & Google maps & 7.16 & 10.71 & -16 & 33 \\
\hline & LATITUTE & $\begin{array}{l}\text { In the North } \\
\text { (higher values) } \\
\text { or in the South } \\
\text { (lower values) }\end{array}$ & Google maps & 47.36 & 8.07 & 28.13 & 61.12 \\
\hline & INLAND & $\begin{array}{l}\text { Dummy variable } \\
\text { that takes value } \\
1 \text { if a port } \\
\text { authority is } \\
\text { located in a } \\
\text { navigable } \\
\text { channel }\end{array}$ & $\begin{array}{c}\text { Containerization } \\
\text { International } \\
\text { Yearbook 2012/ } \\
\text { UNECE Inland } \\
\text { waterway Map } \\
\text { (2012) }\end{array}$ & 0.07 & 0.27 & 0 & 1 \\
\hline & ISLAND & $\begin{array}{l}\text { Dummy variable } \\
\text { that takes a } \\
\text { value of } 1 \text { for } \\
\text { ports located in } \\
\text { islands }\end{array}$ & $\begin{array}{l}\text { Containerization } \\
\text { International } \\
\text { Yearbook } 2012\end{array}$ & 0.12 & 0.33 & 0 & 1 \\
\hline & HUB & $\begin{array}{c}\text { Dummy variable } \\
\text { that takes a } \\
\text { value of } 1 \text { for }\end{array}$ & $\begin{array}{c}\text { Containerization } \\
\text { International } \\
\text { Yearbook } 2012\end{array}$ & 0.04 & 0.20 & 0 & 1 \\
\hline
\end{tabular}

Table 1 Descriptive statistics of the variables used in the empirical analysis 


\begin{tabular}{|c|c|c|c|c|c|c|c|}
\hline \multirow[t]{3}{*}{ Port attributes } & & large hub ports & $\begin{array}{c}\text { / Portopia } \\
\text { Report (2014) }\end{array}$ & & & & \\
\hline & NO_MULTIUSER & $\begin{array}{c}\text { Dummy variable } \\
\text { that takes value } \\
1 \text { if at least one } \\
\text { terminal is } \\
\text { controlled by } \\
\text { Shipping } \\
\text { Company }\end{array}$ & $\begin{array}{l}\text { Annual reports } \\
\text { and port } \\
\text { authorities' } \\
\text { websites }\end{array}$ & 0.15 & 0.36 & 0 & 1 \\
\hline & $\begin{array}{c}\text { TRAFFIC } \\
\text { NEARBY PORTS }\end{array}$ & $\begin{array}{l}\text { Sum of the } \\
\text { volume of } \\
\text { container traffic } \\
\text { of neighbor } \\
\text { ports (up to } 400 \\
\text { miles) }\end{array}$ & $\begin{array}{l}\text { Containerization } \\
\text { International } \\
\text { Yearbook } 2012 \\
\text { and port } \\
\text { distance miles } \\
\text { measured by } \\
\text { google maps }\end{array}$ & 7845447 & $1.10 \mathrm{e}+07$ & 0 & $4.41 \mathrm{e}+07$ \\
\hline \multirow{2}{*}{$\begin{array}{c}\text { Surface } \\
\text { Transporation }\end{array}$} & MOTORWAYS & $\begin{array}{l}\text { Density of } \\
\text { motorways } \\
\text { (Length in } \\
\text { kilometers } \\
\text { divided by area } \\
\text { of country) }\end{array}$ & $\begin{array}{l}\text { Eurostat } \\
\text { database }\end{array}$ & 0.03 & 0.04 & 0 & 0.29 \\
\hline & RAILFACILITY & $\begin{array}{l}\text { Dummy variable } \\
\text { that takes a } \\
\text { value } 1 \text { for } \\
\text { terminals with } \\
\text { trains with more } \\
\text { than } 700 \text { meters } \\
\text { of length }\end{array}$ & $\begin{array}{l}\text { Containerization } \\
\text { International } \\
\text { Yearbook } 2012\end{array}$ & 0.14 & 0.35 & 0 & 1 \\
\hline \multirow{3}{*}{$\begin{array}{c}\text { Governance } \\
\text { Model }\end{array}$} & MARKET & $\begin{array}{c}\text { Dummy variable } \\
\text { that takes value } \\
1 \text { if PA is owned } \\
\text { by a private firm } \\
\text { and set free } \\
\text { market prices }\end{array}$ & $\begin{array}{l}\text { Freire Seoane } \\
\text { and Gonzalez- } \\
\text { Laxe (2003), } \\
\text { ESPO finding } \\
\text { report (2010), } \\
\text { ISL report } \\
\text { (2006) and } \\
\text { annual reports }\end{array}$ & 0.11 & 0.31 & 0 & 1 \\
\hline & BUREAUCRACY & $\begin{array}{l}\text { Dummy variable } \\
\text { that takes value } \\
1 \text { if } \mathrm{PA} \text { is owned } \\
\text { by a public } \\
\text { entity, it is } \\
\text { subject to } \\
\text { regulation of } \\
\text { prices and } \\
\text { receives public } \\
\text { subsidies }\end{array}$ & $\begin{array}{l}\text { Freire Seoane } \\
\text { and Gonzalez- } \\
\text { Laxe (2003), } \\
\text { ESPO finding } \\
\text { report (2010), } \\
\text { ISL report } \\
\text { (2006) and } \\
\text { annual reports }\end{array}$ & 0.64 & 0.48 & 0 & 1 \\
\hline & HYBRID & $\begin{array}{l}\text { Dummy variable } \\
\text { that takes value } \\
1 \text { if } \mathrm{PA} \text { with } \\
\text { local/regional } \\
\text { management, set } \\
\text { free prices and } \\
\text { receive public } \\
\text { subsidy }\end{array}$ & $\begin{array}{l}\text { Freire Seoane } \\
\text { and Gonzalez- } \\
\text { Laxe (2003), } \\
\text { ESPO finding } \\
\text { report (2010), } \\
\text { ISL report } \\
\text { (2006) and } \\
\text { annual reports. }\end{array}$ & 0.25 & 0.43 & 0 & 1 \\
\hline
\end{tabular}


First, as economic and geographic attributes of the region, we include Gross Domestic Product (GDP), location variables, and dummies for inland navigation channels and islands. The expected sign of the GDP variable is positive, since wealthier regions should generate more container traffic due to more demand from maritime transport services. In contrast, the expected sign for the location variables is unclear. On the one hand, the largest ports are located in the North-West of Europe but, on the other, ports located in the Mediterranean Sea (South-East) absorb part of the international trade that originates in Asia and passes through the Suez Canal. We also consider inland port authorities for which the expected sign is negative reflecting smaller regions and smaller local demand. ${ }^{13}$ Finally, the expected sign of the island variable is not clear as the traffic to these peripheral locations is captive so that it is totally dependent on the size of local demand. ${ }^{14}$

Second, in the case of port attributes, we consider a dummy variable for ports that act as large hubs. Here, we include ports that can hold more than 2 million TEUs and which have a higher than $50 \%$ share of transshipment. The expected sign of the variable is positive since these ports should handle more traffic than is predicted by local demand. According to Heaver et al. (2000), shipping line alliances in hubs will have a greater presence and a greater market influence on the decision-making of port authorities in the future.

We also consider a 'no multiuser' variable that takes a value of one in the case of those ports in which at least one terminal is managed and monopolized by a single shipping line. The expected sign of this variable is a priori unclear. On the one hand, such a scenario could weaken competition as one of the port's terminals would be free from any competitive pressure; on the other, a positive sign might be expected as the shipping line would guarantee a certain volume of port traffic.

To this point, the variables for hub ports and no multiuser terminal may work as a proxy for intra-port competition; intra-port competition should be more intense in those ports that are not a hub and those ports where all terminals are multiuser. However, even in these ports intra-port competition may be weak. Dong et al. (2016) find that terminals within a port may have strong incentives to collude in prices, while Van Reeven (2010) shows that intra-port competition (in a landlord port management model) is not in the interest of the port operators because it reduces their profits and prices for the customers.

\footnotetext{
${ }^{13}$ See table in the Annex for a list of all inland port authorities in our database.

${ }^{14}$ Because of its size, we do not consider the United Kingdom as an island.
} 
In addition, we consider a variable for the volume of traffic in neighboring ports, taking into account the number of nearby ports located in a radius of between one hundred and five hundred miles. We then sum the total amount of port traffic for each traffic threshold. The expected sign of this variable is a priori unclear. In the literature, Yap and Lam (2006) reported that port competition only benefits the largest seaports in East Asia that are located in the same hinterland. Likewise, Notteboom (2009), in a study of shipping-line decisions, observed a tendency towards concentration in the Rhine-Scheldt Delta region. In that case, the largest ports acted as substitutes for each other while smaller ports were complements of the large load centers. Hence, in our analysis, the sign should be negative if competition has a substitution effect between major ports in the same region. However, a positive sign might be expected if a complementary effect is dominant. Indeed, the traffic handled by the port could grow due to an increase in the total amount of traffic in the nearby ports as more shipping lines may include it in their routes.

Plainly, transporting goods by inland requires an efficient network infrastructure. So, an increase in corridor capacity increases a port's output and profit and reduces the profit of a rival port (Zhang, 2008). Thus, De Langen (2008) stressed the importance of the port authority as a coordinator capable of enhancing the efficiency of the transport chain and competitive clusters. So as to measure the effect of surface transport modes, we also include explanatory variables related to the endowment of motorways in the country and the endowment of rail facilities within a terminal. In the first case, the endowment of motorways is measured at the country level that could distort our results but data at a more disaggregated level is not available. The expected sign for the motorway variable is unclear since, on the one hand, it might be positive as it could promote greater efficiency in the logistics chain (a complementary effect); yet, on the other hand, it might be negative with maritime traffic losing out to road traffic (substitution effect). Finally, the rail facilities variable is expected to present a positive sign since it should serve to attract more container traffic and to transport it to other regions.

Finally, in the case of the models of port governance we consider three characteristics: regulation, finance and ownership. Specifically, we consider hybrid and bureaucratic system variables, where the reference variable is the market system. The expected sign of these variables is unclear, as there is a dearth of studies explicitly examining the influence of the models of governance on port traffic and so it is difficult to identify a clear relationship 
between the two. However, we can expect a positive sign of the hybrid model variable as the more intense competition that allows the free pricing could allow attracting more traffic. In contrast, the bureaucratic variable model is expected to have a negative sign as it put barriers to competition between ports of the same country subjected to this governance model.

\section{ESTIMATION AND RESULTS}

In this section we show the results of the estimation of the port traffic equation considering various econometric techniques. As we mention above, a limitation of our data is that they refer to just one year. Having said that, several explanatory variables are time invariant (longitude, latitude, inland, island, hub) or have a very low variability over time (no_multiuser, motorways, railfacility, hybrid, bureaucracy). Hence, the added value of a panel dataset (repeated cross-sections over time) for these variables should be modest. Only the variables of port traffic and GDP may be affected by relevant important changes from one year to the other. Note here that the GDP variable is just a control factor, while we must be cautious in the interpretation of results of the traffic of nearby ports variable.

An initial analysis of the distribution of the dependent variable (Figure 3) shows a range of values from extreme to values close to zero, indicating that it is severely positively skewed with a non-normal distribution. A log normalization of the dependent variable was therefore conducted to reduce the skewness (see Figure 4). Note also the importance of considering the non-normal distribution given the small number of observations. 
Figure 2- Traffic distribution

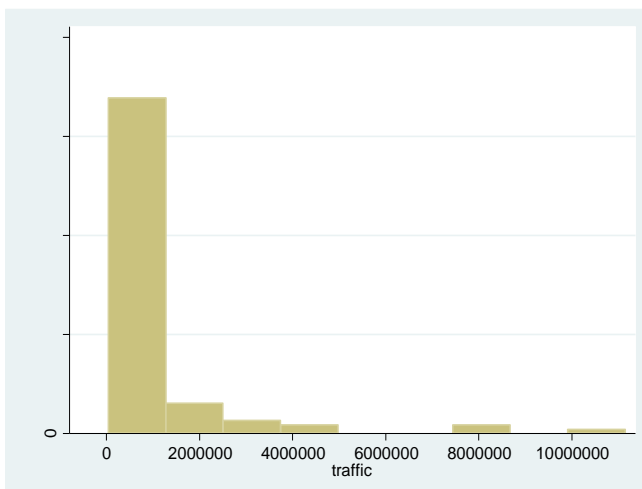

Figure 3- LogTraffic distribution and normal density plot

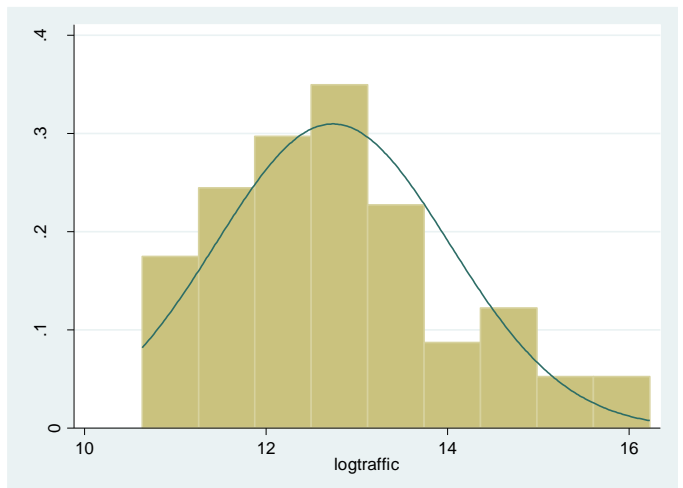

Source: Total of container traffic of 92 European port authorities and based on information obtained from Containerization International Yearbook 2012.

The resulting model of $\log$ normality of the dependent variable appeared to resemble the basic normal distribution, indicating the possibility of estimating an OLS model. However, as Table 2 shows, the Doornik-Hansen test for multivariate normality and the skewness and kurtosis normality test showed that the log-transformed dependent variable continued to follow a non-normal distribution.

Table 2. Econometric normality tests and summary statistics

\begin{tabular}{|l|c|}
\cline { 2 - 2 } \multicolumn{1}{c|}{} & Results of tests \\
\hline N & 92 \\
\hline Mean & 12.723 \\
\hline Standard Deviation & 1.287 \\
\hline $\begin{array}{l}\text { Skewness and kurtosis normality test } \\
\text { (dependent variable) }\end{array}$ & $71.28^{* * *}$ \\
\hline $\begin{array}{l}\text { Skewness and kurtosis normality test } \\
\text { (log transformation dependent variable) }\end{array}$ & $6.30^{* *}$ \\
\hline Doornik Hansen test for multivariate normality & $2931.008^{* * *}$ \\
\hline $\begin{array}{l}\text { Note 1: Standard errors in brackets. } \\
\text { Note 2: Statistical significance at 1\% }(* *), 5 \%(* *), 10^{* *}(*)\end{array}$
\end{tabular}

Several studies in the fields of insurance, health and transportation (Manning and Mullhay, 2001; de Jong and Heller, 2008; Hill and Miller, 2010 and Tyworth and Zeng, 1998) have used dependent variables with a positively skewed distribution. These analyses indicate, however, that distributional problems can occur, resulting in substantial bias in the OLS regression. We, therefore, considered different classes of regression models based on the Generalized Linear Model (GLM) in which the log-link function could be implemented without imposing a transformation of the dependent variable. In addition, our estimations may present a problem of heteroscedasticity in the error term. To correct this, we applied 
robust standard errors in all our analyses. Indeed, Cameron and Trivedi (2009) recommend using robust standard errors for parameter estimates in some count-data models.

An alternative to the OLS regression is a Poisson model. Statistical theory considers that in a Poisson distribution the conditional variance is equal to the conditional mean. In order to determine whether our model satisfied this assumption, we calculated the Pearson dispersion statistic. This goodness-of-fit test is defined as the Pearson statistic divided by the model's degrees of freedom (DF) which should give a value of around one (Hilbe, 2007). A result greater than one, however, might indicate over-dispersion, while a result lower than one would indicate under-dispersion. Such a situation could lead to the incorrect estimation of the standard errors. In our case, the ratio of the Pearson statistic to the DF was equal to 1062245 , clearly indicative of an over-dispersion problem, and as a consequence, the Poisson distribution is not a good choice in our estimation process.

Given the problem of over-dispersion, we had to consider alternative models. Alternatives include a negative binomial distribution (Cameron and Trivedi, 2009; Hilbe, 2007) or a gamma distribution model. In the first case, the ratio of the Pearson statistic to the DF was equal to 1.02 , i.e., almost 1 , close to the goodness-of-fit statistic. In the second case, the ratio of the Pearson statistic to the DF is also equal to 1.02 , i.e., almost 1 , close to the goodness-of-fit statistic too.

The gamma distribution assumes that the standard deviation is proportional to the mean and can be used when the dependent variable is continuous and does not present a normal distribution. In our analysis, the dependent variable presents positive integer values but the number of counts is so high that it resembles a continuous variable. Consequently, the gamma distribution is a better alternative than the negative binomial model.

Moreover, we need to consider the possibility that some endogenous explanatory variables might bias the estimation results. In particular, there may be a simultaneous determination of traffic and the Gross Domestic Product (GDP), so that the GDP variable may be endogenous; thus, in our estimation we considered the lag of GDP variable as explanatory variable as it is hard to assume that the GDP in 2009 is dependent upon traffic in 2010. Note that the use of additional lags of the GDP variable does not change the results of the empirical analysis

Finally, we need to take into account the potential problem of multicollinearity due to the high correlation between the explanatory variables. Table 3 shows that the results of 
the variance inflation factor are lower than 4 in the equation considered, so we can conclude that there is no problem of multicollinearity.

Table 3: Variance inflation factor

\begin{tabular}{|c|c|}
\cline { 2 - 2 } \multicolumn{1}{c|}{} & VIF \\
\hline Log Traffic & 1.66 \\
\hline GDP 2009 & 1.26 \\
\hline Longitude & 1.70 \\
\hline Latitude & 3.04 \\
\hline Island & 1.49 \\
\hline Inland & 1.16 \\
\hline Hub & 1.44 \\
\hline Traffic200 & 1.43 \\
\hline No_multiuser & 1.49 \\
\hline Motorways & 1.75 \\
\hline Rail facility & 1.57 \\
\hline Hybrid & 2.94 \\
\hline Bureaucracy & 3.90 \\
\hline MEAN VIF & $\mathbf{1 . 9 1}$ \\
\hline
\end{tabular}

We estimated the GLM with a gamma distribution for different distances of nearby ports in order to select which is most appropriate for our analysis. ${ }^{15}$ In order to select one nearby port distance threshold as explanatory variable, we used different information criteria using goodness-of-fit statistics. Generally, there are two standard measures for a selection test for different estimations, namely, Akaike's information criterion (AIC) and Schwarz's Bayesian information criterion (BIC), where a smaller AIC and BIC are preferred (Cameron and Trivedi, 2009). However, and according to Hilbe (2007), most statisticians today prefer to use the AIC, BIC, or other model-specific fit statistics to the deviance. For this reason, we do not consider deviance goodness-of-fit statistics here. As a result, in the gamma distribution model using all thresholds for nearby port distances, the variable of port traffic in a 400-mile radius presents the lowest AIC and BIC values and so we have opted to consider this distance threshold in our preferred regressions. In any case, only the GDP and traffic in the nearby port variables are affected by the consideration of one or other of the measures of traffic handled in nearby ports.

15 The details of the gamma distribution model using all thresholds for nearby port distances are available from the authors. 
Table 4 reports the results of the equation of traffic in European ports using three estimation methods. The first column shows the results for the OLS regression, while the second and third columns show the results for the GLM using a negative binomial distribution and a gamma distribution, respectively. As can be observed, the estimation results when using the negative binomial and the gamma distribution techniques do not change. Recall that the results obtained with these two techniques should be more accurate in our context than those obtained with OLS. In any case, the result in table 4 suggests that the estimation is less precise when using OSL as some variables loss statistical significance when using this method.

Table 4. Results of the traffic equation comparing different model techniques

\begin{tabular}{|c|c|c|c|}
\hline & $\begin{array}{l}\text { Log Traffic } \\
\text { (OLS) }\end{array}$ & $\begin{array}{l}\text { Log Traffic } \\
\text { (NB) }\end{array}$ & $\begin{array}{c}\text { Log Traffic } \\
\text { (Gamma) }\end{array}$ \\
\hline GDP 2009 & $\begin{array}{c}1.24 \mathrm{e}-06 \\
(1.42 \mathrm{e}-06)\end{array}$ & $\begin{array}{c}2.22 \mathrm{e}-06 \\
(1.59 \mathrm{e}-06)\end{array}$ & $\begin{array}{c}2.22 \mathrm{e}-06 \\
(1.59 \mathrm{e}-06)\end{array}$ \\
\hline Longitude & $\begin{array}{c}0.0114 \\
(0.0125)\end{array}$ & $\begin{array}{l}0.00805 \\
(0.0109)\end{array}$ & $\begin{array}{l}0.00805 \\
(0.0109)\end{array}$ \\
\hline Latitude & $\begin{array}{l}-0.0338 \\
(0.0204)\end{array}$ & $\begin{array}{c}-0.0428^{* *} \\
(0.0192)\end{array}$ & $\begin{array}{c}-0.0428^{* *} \\
(0.0192)\end{array}$ \\
\hline Island & $\begin{array}{l}0.0822 \\
(0.426)\end{array}$ & $\begin{array}{l}-0.0387 \\
(0.334)\end{array}$ & $\begin{array}{l}-0.0387 \\
(0.334)\end{array}$ \\
\hline Inland & $\begin{array}{l}-0.466^{*} \\
(0.245)\end{array}$ & $\begin{array}{c}-0.949 * * * \\
(0.272)\end{array}$ & $\begin{array}{c}-0.949 * * * \\
(0.272)\end{array}$ \\
\hline Traffic_nearby_ports & $\begin{array}{c}1.46 \mathrm{e}-08 \\
(1.93 \mathrm{e}-08)\end{array}$ & $\begin{array}{l}2.60 \mathrm{e}-08 * \\
(1.52 \mathrm{e}-08)\end{array}$ & $\begin{array}{l}2.60 \mathrm{e}-08^{*} \\
(1.52 \mathrm{e}-08)\end{array}$ \\
\hline Hub & $\begin{array}{c}1.574 * * * \\
(0.431)\end{array}$ & $\begin{array}{c}1.254 * * * \\
(0.480)\end{array}$ & $\begin{array}{c}1.254^{* * *} * \\
(0.480)\end{array}$ \\
\hline No_Multiuser & $\begin{array}{l}1.007^{* *} \\
(0.439)\end{array}$ & $\begin{array}{l}0.902^{* *} \\
(0.364)\end{array}$ & $\begin{array}{l}0.902^{* *} \\
(0.364)\end{array}$ \\
\hline Motorways & $\begin{array}{l}-3.899 \\
(2.610)\end{array}$ & $\begin{array}{l}-3.217 \\
(2.851)\end{array}$ & $\begin{array}{l}-3.217 \\
(2.851)\end{array}$ \\
\hline rail facility & $\begin{array}{l}0.992^{*} \\
(0.533)\end{array}$ & $\begin{array}{c}1.268^{* * *} \\
(0.456)\end{array}$ & $\begin{array}{c}1.268^{* * *} \\
(0.456)\end{array}$ \\
\hline Hybrid & $\begin{array}{l}-0.429 \\
(0.510)\end{array}$ & $\begin{array}{l}-0.455 \\
(0.410)\end{array}$ & $\begin{array}{l}-0.455 \\
(0.410)\end{array}$ \\
\hline bureaucracy & $\begin{array}{l}-0.511 \\
(0.477)\end{array}$ & $\begin{array}{l}-0.673^{*} \\
(0.398)\end{array}$ & $\begin{array}{l}-0.673^{*} \\
(0.398)\end{array}$ \\
\hline Constant & $\begin{array}{c}14.26^{* * *} \\
(1.172) \\
\end{array}$ & $\begin{array}{c}15.13^{* * *} \\
(1.065) \\
\end{array}$ & $\begin{array}{c}5.13^{* * *} \\
(1.065) \\
\end{array}$ \\
\hline Number observations & 86 & 86 & 86 \\
\hline $\mathbf{R}^{2}$ & 0.401 & - & - \\
\hline Joint significance test & 8.597 & - & - \\
\hline AIC & - & 28.73 & 28.73 \\
\hline BIC & - & -246.4 & -246.4 \\
\hline Pearson /DF & - & 1.044 & 1.044 \\
\hline
\end{tabular}

Note 1: Robust Standard errors in brackets.

Note 2: Statistical significance at $1 \%(* * *), 5 \%(* *), 10 \%\left(^{*}\right)$ 
Table 5 shows the results of the estimation of the traffic equation using the GLM with a gamma distribution. As mentioned above, although the results of the negative binomial and gamma distribution are similar, we opted to use the gamma distribution as our preferred method because our dependent variable resembles a continuous variable. The first column shows the results when considering the geographic attributes, the second when adding port competition variables, the third when adding surface transportation variables, and the fourth when considering all explanatory variables.

Table5. Results of the traffic equation

\begin{tabular}{|c|c|c|c|c|}
\hline & $\begin{array}{c}\text { Log Traffic } \\
\text { (Gamma) }\end{array}$ & $\begin{array}{c}\text { Log Traffic } \\
\text { (Gamma) }\end{array}$ & $\begin{array}{c}\text { Log Traffic } \\
\text { (Gamma) }\end{array}$ & $\begin{array}{c}\text { Log Traffic } \\
\text { (Gamma) }\end{array}$ \\
\hline GDP 2009 & $\begin{array}{c}1.70 \mathrm{e}-06 \\
(2.45 \mathrm{e}-06)\end{array}$ & $\begin{array}{c}9.45 \mathrm{e}-07 \\
(1.77 \mathrm{e}-06)\end{array}$ & $\begin{array}{c}1.30 \mathrm{e}-06 \\
(1.55 \mathrm{e}-06)\end{array}$ & $\begin{array}{l}2.22 \mathrm{e}-06 \\
(1.59 \mathrm{e}-06)\end{array}$ \\
\hline Longitude & $\begin{array}{l}-0.0185 \\
(0.0137)\end{array}$ & $\begin{array}{c}0.00162 \\
(0.00802)\end{array}$ & $\begin{array}{c}0.000591 \\
(0.0107)\end{array}$ & $\begin{array}{l}0.00805 \\
(0.0109)\end{array}$ \\
\hline Latitude & $\begin{array}{l}0.00126 \\
(0.0255)\end{array}$ & $\begin{array}{l}-0.0218 \\
(0.0133)\end{array}$ & $\begin{array}{l}-0.0266^{*} \\
(0.0149)\end{array}$ & $\begin{array}{c}-0.0428^{* *} \\
(0.0192)\end{array}$ \\
\hline Island & $\begin{array}{l}-0.563 \\
(0.546)\end{array}$ & $\begin{array}{l}-0.225 \\
(0.292)\end{array}$ & $\begin{array}{c}-0.0942 \\
(0.335)\end{array}$ & $\begin{array}{l}-0.0387 \\
(0.334)\end{array}$ \\
\hline Inland & $\begin{array}{c}-1.397 * * * \\
(0.353)\end{array}$ & $\begin{array}{c}-0.714^{* *} \\
(0.341)\end{array}$ & $\begin{array}{c}-0.805^{* * *} \\
(0.310)\end{array}$ & $\begin{array}{c}-0.949 * * * \\
(0.272)\end{array}$ \\
\hline Traffic_nearby_ports & - & $\begin{array}{c}5.22 \mathrm{e}-08 * * * \\
(1.42 \mathrm{e}-08)\end{array}$ & $\begin{array}{c}3.48 \mathrm{e}-08^{* *} \\
(1.37 \mathrm{e}-08)\end{array}$ & $\begin{array}{l}2.60 \mathrm{e}-08^{*} \\
(1.52 \mathrm{e}-08)\end{array}$ \\
\hline Hub & - & $\begin{array}{l}0.996 * * \\
(0.391)\end{array}$ & $\begin{array}{c}1.310^{* * *} \\
(0.481)\end{array}$ & $\begin{array}{c}1.254^{* * * *} \\
(0.480)\end{array}$ \\
\hline No_Multiuser & - & $\begin{array}{c}1.031 * * * \\
(0.339)\end{array}$ & $\begin{array}{c}0.855^{* *} \\
(0.367)\end{array}$ & $\begin{array}{l}0.902 * * \\
(0.364)\end{array}$ \\
\hline Motorways & - & - & $\begin{array}{l}-2.937 \\
(2.870) \\
\end{array}$ & $\begin{array}{l}-3.217 \\
(2.851)\end{array}$ \\
\hline rail facility & - & - & $\begin{array}{c}1.074^{* *} \\
(0.417)\end{array}$ & $\begin{array}{c}1.268^{* * *} \\
(0.456)\end{array}$ \\
\hline Hybrid & - & - & - & $\begin{array}{l}-0.455 \\
(0.410)\end{array}$ \\
\hline Bureaucracy & - & - & - & $\begin{array}{l}-0.673^{*} \\
(0.398)\end{array}$ \\
\hline Constant & $\begin{array}{c}13.77 * * * \\
(1.222)\end{array}$ & $\begin{array}{c}13.67 * * * \\
(0.670)\end{array}$ & $\begin{array}{c}13.90^{* * *} \\
(0.706)\end{array}$ & $\begin{array}{c}15.13^{* * *} \\
(1.065)\end{array}$ \\
\hline Number observations & 91 & 91 & 86 & 86 \\
\hline AIC & 29.41 & 28.70 & 28.71 & 28.73 \\
\hline BIC & -221.9 & -278.9 & -253.3 & -246.4 \\
\hline
\end{tabular}

Note 1: Robust standard errors in brackets.

Note 2: Statistical significance at $1 \%(* * *), 5 \%(* *), 10 \%(*)$

Note that because of a lack of data for some explanatory variables, our sample is reduced from 91 to 86 observations. The following conclusions can be drawn from the results of our regressions. 
The coefficient associated with the GDP variable (column 1) is positive and not statistically significant (although it is statistically significant when the construction of the variable capturing the traffic in nearby ports is calculated at the 100-, 200- and 300-mile radius). Thus, it would seem that the economic activity of the region in which the port authority is located may have a positive influence on container traffic, although the effect is not strong from a statistical point of view. A possible explanation of this result is that the hinterland of the port extends beyond the local region in which the port is located.

In the case of the location variables, the coefficient associated with the longitude variable is negative but not statistically significant, while the coefficient associated with the latitude variable is positive and not statically significant. This seems to indicate that ports located in the North-West have more traffic. The island coefficient is also negative and does not reach statistically significant levels. This result can be explained by the peripheral characteristics of these ports, which means the existence of a large captive traffic making the ports totally dependent on local demand. Finally, the coefficient associated with the inland port variable is negative and statistically significant, indicating that ports located in a navigable channel manage lower volumes of container traffic given that their traffic is related exclusively to their (small) local hinterlands.

If we only consider a region's economic and geographic attributes, almost all the variables are not statistically significant. This means it is essential to include additional variables to explain the determinants of port traffic.

The coefficient associated with the number of ports located within a 400 -mile radius (column 2), when also controlling for economic and geographic attributes, is positive and statistically significant. Thus, we find evidence of a complementary effect whereby the traffic handled by a port might grow due to an increase in traffic in a nearby port. This can be explained by the strategies adopted by shipping lines that operate regular lines and which stop at several ports that are located close to each other.

Importantly, the coefficient of the large hub port variable is also positive and statistically significant. This, as discussed, can be attributed to the fact that ports with a greater share of transshipment traffic are able to generate more traffic than is otherwise predicted by their regional attributes. This result is in line with that obtained for the variable of the 'no multiuser' terminal. The coefficient of this variable is positive and statistically significant. Thus, a terminal managed by a shipping line company would seem to guarantee the 
movement of more container traffic given the values of the other control variables. Here, it may be the case that intra-port competition in cases where there are more opportunities for that (non-hub ports, port with all terminals as multiuser) is weak in practice. It may be also the case that all terminal operators within a port share common resources and common bottlenecks which is what it essentially drives the aggregate amount of traffic that a port is able to generate.

The above results do not change significantly when considering the surface transportation variables (column 3), while continuing to control for the economic and geographic variables and the port attributes. Only the coefficient associated with the latitude variable becomes negative and statistically significant. Thus, the coefficient associated with the endowment of motorways is negative but not statistically significant, suggesting that the complementary effect between ports and motorways is offset by the substitution effect, with the greater volume of freight transport by road reducing port traffic. Note here that according to Eurostat, in 2012 the percentage of inland freight transport by road in Europe was $75.1 \%$, compared to $18.2 \%$ by rail and $6.7 \%$ by inland waterways (Eurostat, 2012. Units: \% of total inland tkm). In contrast, the coefficient associated with the rail facility variable is positive and statistically significant. This means that if a railroad track is operated within the terminal (being able to move trains with more than 700 meters of length), this intermodal infrastructure may help the port to attract more traffic.

Finally, when controlling for all the above explanatory variables, the coefficient associated with the hybrid variable is negative and not significant, while the coefficient associated with the bureaucratic variable is negative and statistically significant (column 4). Thus, we find evidence that ports with fixed-price regulation, central government ownership and public finance, negatively affect the attraction of port traffic. Consequently, a more market-oriented governance model seems to be positive for port traffic. As such, we would expect ports located in the North to have more competitive advantages than the ports located in the South that are subject to a bureaucratic system of port governance.

\section{CONCLUSION}

Competition between European port authorities can be associated with the effects of distant large transshipment ports as well as with local nearby ports. A more competitive 
scenario can increase a port's traffic due to incentives to be more efficient; yet, at the same time, this competition might also reduce the volume of traffic handled by less efficient ports. Here, controlling for several factors, we have examined whether ports benefit from a more competitive scenario.

Overall, we can infer from our results that competition between ports may boost traffic. Indeed, ports may benefit from being located near to other large ports and from a more market-oriented governance model. In contrast, we do not find clear evidence that competition within the port spur traffic. Controlling for other factors, hub ports are able to generate more traffic. Hub ports are typically subject to an intense rivalry with other ports but they tend to be dominated by one shipping line. In this regard, traffic tends to be higher in ports that have a terminal managed by a shipping line. Finally, we also find that the connectivity with rail facilities is a major determinant of the ability of a port to attract traffic.

As such, our results indicate that Southern European port authorities present specific characteristics that may undermine their competitive position. The Mediterranean port authorities are generally managed in accordance with the bureaucratic model of governance and operate few rail facilities within the port terminals. Although Mediterranean ports enjoy global connectivity in international shipping networks, it is difficult for them to extend their rail services in their own hinterlands (Notteboom, 2010). The OECD (2008) also observes an imbalance in geographical traffic flows between the North and South and concludes that the Northern region is likely to enjoy greater growth due to better hinterland transport conditions.

In conclusion, Southern European port authorities need to consider adopting more flexible systems of governance in order to attract more traffic and to ensure greater efficiency. Furthermore, they should also consider the possibility of experimenting with different port governance models within the same region. In this way, the largest ports could be managed with more flexible systems so that they can increase their financial resources and invest in the port authority's facilities, including better railway links. Likewise, ports in Southern Europe should be not so concerned by nearby ports and they could put the attention on their competitiveness in relation to port authorities in North of Europe. 
A limitation of this analysis has been the lack of data preventing us from extending the analysis beyond a period of one year. Further research could usefully examine the influence of additional factors including the economic crisis or situations of over-investment. Similarly, future studies should examine in greater depth the dynamic relationship between competition, efficiency and traffic. 
Acknowledgements: The authors acknowledge financial support from the Spanish Ministry of Economy and Competitiveness (ECO2012-38004) and the Regional Government of Catalonia (SGR2014-325).

\section{REFERENCES}

Arbués,P., Baños, JF, and Mayor, M (2015) "The Spatial Productivity of Transportation Infrastructure", Transportation Research Part A, 75, 166-177.

Barros, C., and Athanassiou, M. (2004), "Efficiency in European Seaports with DEA: Evidence from Greece and Portugal", Maritime Economics and Logistics, 6, 122-40.

Bae, MJ, Chew, EP, Lee, LH, and Zhang, A (2013) "Container transshipment and port competition", Maritime Policy and Management, 40 (5), 479-494.

Bottasso, A., Conti, M., Ferrari, C., Merk, O and Tei, A (2013) "The impact of port throughput on local employment: Evidence from a panel of European regions," Transport Policy, 27, 32-38.

Brooks, M.R. (2004) "The Governance Structure of Ports", Review of Network Economics, 3 (2), 168-183.

Cameron, A.C and Trivedi, P.K (2009) Microeconometrics Using Stata, A Stata Press Publication. SttaCorp LP, College Station, Texas.

Castillo-Manzano, JI, Gonzalez-Laxe, F and López-Valpuesta, L (2013) "Intermodal connections at Spanish Ports and their role in capturing hinterland traffic", Ocean and Coastal Management, 1-12.

Castillo Manzano, J.I., Valpuesta, L.L., and Pérez García, J.J. (2008), "Economic Analysis of the Spanish Port Sector Reform During the 1990s", Transportation Research Part A, 42 (8), 1056-1063

Cheon,S., Dowall, D. and Song, D. (2010). "Evaluating impacts of institutional reforms on port efficiency changes: Ownership, corporate structure, and total factor productivity changes of world container ports". Transportation Research Part E. 46, 546-561.

Containerization International Yearbook 2012; Informa UK Publication, London

Czerny, A., Höffler, F and Mun, S-I (2014), "Hub port competition and welfare effects of strategic privatization", Economics of Transportation, 3 (3), 211-220.

Cullinane, K. P. B., Song, D-W., and Gray, R. (2002), "A Stochastic Frontier Model of the Efficiency of Major Container Terminals in Asia: assessing the Influence of Administrative and Ownership Structures", Transportation Research Part A, 36, 743-62.

De Borger, Proost, S and Van Dender,K. (2008) "Private Port Pricing and Public Investment in Port and Hinterland Capacity", Journal of Transport Economics and Policy, 42(3), 527-561

De Jong, P., and Heller, G. Z. (2008) Generalized Linear Models for Insurance Data, Cambridge, UK: Cambridge University Press.

De Langen, P.W (2008), "Ensuring Hinterland Access: The Role of Port Authorities", Discussion Paper No.2008-11, Joint Transport Research Centre, International Transport Forum (OECD). 
Dong, G., Huang, R., Ng, P. (2016), “Tacit collusion between two terminals of a port", Transportation Research Part E, 93 (1), 199-211.

ESPO Report (2010) “The Espo Fact-Finding Report 2010: European Port Governance, Report of an enquiry into the current governance of European Seaport", ESPO Publication.

Estache, A., González, G., and Trujillo, L. (2002), "Efficiency Gains from Port Reform and the Potential for Yardstick Competition: Lessons from Mexico", World Development, 30(4), 545-60.

Fageda, X., and Gonzalez-Aregall, M. (2015) "The spatial effects of transportation on economic employment" Working Paper.

Fageda, X., and Gonzalez-Aregall, M. (2014) "Port charges in Spain: The roles of regulation and market forces" International Journal of Shipping and Transport Logistics, 6 (2), $152-171$.

Ferrari, C, Percoco, M, and Tedeschi, A (2010) "Ports and Local development: Evidence from Italy," International Journal of Transport Economics. 37 (1), 9-30.

Figueiredo De Oliveira, G., and Cariou, P. (2015), "The impact of competition on container port (in)efficiency", Transportation Research Part A, 78, 124-133.

Freire Seoane, M.J, and Gonzalez-Laxe, F (2003). Economia del Transporte maritimo. (1st Edition). Edited by Netbiblo and Instituto Universitario de Estudios Marítimos (IUEM).

Garcia-Alonso, L and Martin-Bofarull,M (2007) "Impact of port investment on efficiency and capacity to attract traffic in Spain: Bilbao versus Valencia", Maritime Economics and logistics, 9(3), 254-267.

González, M. M., and Trujillo, L. (2008), "Reforms and Infrastructure Efficiency in Spain's Container Ports", Transportation Research Part A, 42(1), 243-57.

González, M.M., Trujillo, L. (2009), "Efficiency measurement in the port industry: A survey of the empirical evidence", Journal of Transport Economics and Policy, 43, 157-192.

Heaver, T, Meersman, H, Moglia, F and Van de Voorde, E (2000) "Do mergers and alliances influence European shipping and port competition?" Maritime Policy and Management, 27 (4), 363-373.

Hilbe,J.M. (2007) Negative Binomial Regression, (1st Edition), Cambridge University Press.

Hill, S.C. and Miller, G.E. (2010) "Health Expenditure Estimation and Functional Form: Applications of the Generalized Gamma and Extended estimating equations models", Health Economics, 19, 608-627.

ISL report (2006) Public Financing and Charging Practices of Seaports in the EU, Institute of Shipping Economics and Logistics, Bremen.

ITF report (2010) Maritime Transportation: Drives for the Shipping and Port Industries, International Transport Forum, Forum Papers, num. 2, OECD.

Liu, Z. (1995), The Comparative Performance of Public and Private Enterprise. The case of British Ports, Journal of Transport Economics and Policy, 29, 263-74.

Manning, W. G., and Mullahy, J. (2001), Estimating Log Models: To Transform or Not to Transform?, Journal of Health Economics 20, 461-494. 
Ng, K.Y (2006) "Assessing the Attractiveness of Ports in the North European Container Transhipment Market: An Agenda for Future Research in Port Competition", Maritime Economics and Logistics, 8, 234-250.

Notteboom, T. (2009) "Complementarity and substitutability among adjacent gateway ports", Environmental and Planning A, 41, 743-762.

Notteboom, T. (2010) "Concentration and the formation of multi-port gateway regions in the European container port system: an update", Journal Transport Geography, 18, 567-583.

Notteboom, T. and Rodrigue, J.-P (2012) "The corporate geography of global container terminal operators", Maritime Policy and Management, 39(3), pp. 249-279

Notteboom, T. and Verhoeven, P. (2010) "The awarding of seaport terminals to private operators: European practices and policy implications”, European Transport, 45, 83-101.

Notteboom, T, Verhoeven, P and Fontanet, M (2012), "Current practices in European ports on the awarding of seaport terminals to private operators: towards an industry good practice guide", Maritime Policy and Management, 39 (1), 107-123.

OECD (2008) "Port Competition and Hinterland Connections", Joint Transport Research Centre, Discussion Paper 2008-19, Published by OECD and International Transport Forum

OECD (2011) Competition in Ports and Port Services, Policy Round Tables

Pallis, A (2007), "EU Port Policy: Implications for port governance in Europe", Devolution, Port Governance and Port Performance (Chapter 21). Research in Transportation Economics, 17, 479-495.

Portopia Report (2014) 'Partim Transshipment Volumes: State of the European Port System-Market Trends and Structure Update", $7^{\text {th }}$ Framework Programme.

Shan, J, Yu, M, and Lee, C-Y (2014) “An Empirical Investigation of the Seaport's Economic Impact: Evidence from Major Ports in China", Transportation Research Part E, 69, 41-53.

Stopford, M (2009) Maritime Economics (Third Ed) Routledge Taylor and Francis Group

Tongzon,J and Heng,W. (2005) "Port privatization, efficiency and competitiveness: some empirical evidence from container ports terminals", Transport Research Part A, 39, 405424.

Tovar, B, Trujillo, L. and Jara-Díaz, S (2004) Organization and regulation of the port industry: Europe and Spain. Essays on Microeconomics and Industrial Organization 2nd Edition, Springer-Verlag, Heidelberg, 189-207.

Trujillo, L and Tovar, B (2007) "The European Port Industry: An Analysis of its Economic Efficiency", Maritime Economics and Logistics, 9 (2), 148-171.

Trujillo, L. and Tovar, B. (2012) "Análisis de terminals portuarias: Competencia versus regulación”, Papeles de Economia Española (131), 128-139.

Tyworth, J.E. and Zeng A.Z. (1998) "Estimating the effects of carrier transit-time performance on logistics cost and service", Transportation Research Part A, 32(2), 89-97.

UNCTAD (2013) Review of Maritime Transport, Publish by UNCTAD

UNECE (2012) Map of the European Inland Waterway Network, Published by UNECE

Van Klink, H.A and Van den Berg, G.C (1998), "Gateways and intermodalism”, Journal of Transport Geography, 6(1), 1-9 
Van Reeven, P (2010), “The effect of Competition on Economics Rents in Seaports". Journal of Transport Economics and Policy, 44 (1), 79-92.

Verhoeven, P. (2009), "European Ports Policy: Meeting Contemporany Governance Challenges", Maritime Policy and Management, 36 (1), 79-101.

Verhoeven, P and Vanoutride, T. (2012), "A quantitive analysis of European port governance", Maritime Economics and Logistics, 14, 178-203

Wan, Y and Zhang, A (2013) Urban Road Congestion and Seaport Competition, Journal of Transport Economics and Policy, 47(1), 55-70.

Wang, T.F. and Cullinane, K. (2006) "The efficiency of European Container Terminals and Implications for Supply Chain Management", Maritime Economics and Logistics, 8, 82-99

Wilmsmeier, G, Monios, J and Lambert,B (2011) "The directional development of intermodal freight corridors in relation to Inland terminals", Journal Transport Geography, 19, 1379-1386.

World Bank (2007) “Module 3: Alternative Port Management Structures and Ownership Models", Port Reform Toolkit ( $2^{\text {nd }}$ Edition)

Xiao, Y, Ng, A, Yang, H and Fu,X. (2012) "An analysis of the Dynamics of Ownership, Capacity Investments and Pricing Structure of Ports", Transport Reviews, 32 (5), 629-652.

Yap, W.Y and Lam, J (2006) "Competition dynamics between container ports in East Asia", Transportation Research Part A, 40, 35-51

Yuen, A.C-I, Zhang, A and Chueng, W. (2012) 'Port competitiveness from the users' perspective: An analysis of major container ports in China and its neighboring countries" Research in Transportation Economics, 35, 34-40.

Turner, H., R. J. Windle, and Dresner, M. (2004), "North American Containerport Productivity: 1984-1997”, Transportation Research Part E, 40(4), 339-56.

Zhang, A. (2008) "The Impact of Hinterland Access Conditions on Rivarly between Ports”, Discussion Paper No. 2008-8, Joint Transport Research Centre, International Transport Forum (OECD). 
ANNEX- Table:

Table A1: Port Authorities list

\begin{tabular}{|c|c|c|c|c|c|c|c|c|c|}
\hline $\begin{array}{l}\text { Million of } \\
\text { TEUs }\end{array}$ & Port & $\begin{array}{c}\text { Country } \\
\text { codes }\end{array}$ & traffic & $\operatorname{tax}$ & funds & PA'sproperty & market & bureaucracy & hybrid \\
\hline \multirow{3}{*}{ More than 5} & Rotterdam & NL & 11145804 & free & own & municipality & 0 & 0 & 1 \\
\hline & Antwerp & $\mathrm{BE}$ & 8468475 & free & external & municipality & 0 & 0 & 1 \\
\hline & Hamburg & $\mathrm{DE}$ & 7900000 & free & external & municipality & 0 & 0 & 1 \\
\hline \multirow{3}{*}{ From 3 to 5} & Bremen/Bremerhaven & $\mathrm{DE}$ & 4871297 & free & external & municipality & 0 & 0 & 1 \\
\hline & Valencia & ES & 4206937 & law & external & state & 0 & 1 & 0 \\
\hline & Felixtowe & UK & 3400000 & free & own & private & 1 & 0 & 0 \\
\hline \multirow{11}{*}{ From 1 to 3} & GioiaTauro & IT & 2851261 & law & external & state & 0 & 1 & 0 \\
\hline & Algeciras & ES & 2810242 & law & external & state & 0 & 1 & 0 \\
\hline & Zeebrugge & $\mathrm{BE}$ & 2389879 & free & external & municipality & 0 & 0 & 1 \\
\hline & Marsaxlokk & MT & 2370729 & law & external & state & 0 & 1 & 0 \\
\hline & Le Havre & FR & 2358077 & law & external & state & 0 & 1 & 0 \\
\hline & Barcelona & ES & 1945735 & law & external & state & 0 & 1 & 0 \\
\hline & Genoa & IT & 1758858 & law & external & state & 0 & 1 & 0 \\
\hline & Southampton & UK & 1540000 & free & own & private & 1 & 0 & 0 \\
\hline & La Spezia & IT & 1285455 & law & external & state & 0 & 1 & 0 \\
\hline & Duisburg & $\mathrm{DE}$ & 1181000 & free & external & municipality & 0 & 0 & 1 \\
\hline & Las Palmas & ES & 1113262 & law & external & state & 0 & 1 & 0 \\
\hline \multirow{14}{*}{ From 0.5 to 1} & Marseilles & FR & 953435 & law & external & state & 0 & 1 & 0 \\
\hline & Gothenburg & SE & 796000 & free & own & municipality & 0 & 0 & 1 \\
\hline & Liverpool & UK & 681414 & free & own & private & 1 & 0 & 0 \\
\hline & Leghorn & IT & 635270 & law & external & state & 0 & 1 & 0 \\
\hline & Bordeaux & FR & 632407 & law & external & state & 0 & 1 & 0 \\
\hline & Taranto & IT & 581936 & law & external & state & 0 & 1 & 0 \\
\hline & Cagliari & IT & 576092 & law & external & state & 0 & 1 & 0 \\
\hline & Constrantza & RO & 556694 & law & external & state & 0 & 1 & 0 \\
\hline & Dublin & IE & 554260 & law & external & state & 0 & 1 & 0 \\
\hline & Naples & IT & 532432 & law & external & state & 0 & 1 & 0 \\
\hline & Bilbao & ES & 531457 & law & external & state & 0 & 1 & 0 \\
\hline & Pireaus & EL & 513319 & law & own & state & 0 & 1 & 0 \\
\hline & Lisbon & PT & 512789 & law & external & state & 0 & 1 & 0 \\
\hline & Gdansk & PL & 508587 & law & external & municipality & 0 & 1 & 0 \\
\hline \multirow{23}{*}{ Less than 0.5} & Leixoes & PT & 481784 & law & external & state & 0 & 1 & 0 \\
\hline & Gdynia & $\mathrm{PL}$ & 480142 & law & external & municipality & 0 & 1 & 0 \\
\hline & Koper & SI & 476731 & law & external & state & 0 & 1 & 0 \\
\hline & Teesport & UK & 469096 & free & own & private & 1 & 0 & 0 \\
\hline & Aarhus & $\mathrm{DK}$ & 447000 & free & own & municipality & 0 & 0 & 1 \\
\hline & Helsinki & FI & 399903 & free & own & municipality & 0 & 0 & 1 \\
\hline & Kotka & FI & 397286 & free & own & municipality & 0 & 0 & 1 \\
\hline & Venice & IT & 393913 & law & external & state & 0 & 1 & 0 \\
\hline & Sines & PT & 382089 & law & external & state & 0 & 1 & 0 \\
\hline & Strasbourg & FR & 360938 & law & external & state & 0 & 1 & 0 \\
\hline & Tenerife & ES & 357472 & law & external & state & 0 & 1 & 0 \\
\hline & Limassol & $\mathrm{CY}$ & 348861 & law & external & state & 0 & 1 & 0 \\
\hline & Paris & FR & 345000 & law & external & state & 0 & 1 & 0 \\
\hline & Helsingborg & SE & 320000 & free & own & state & 1 & 0 & 0 \\
\hline & Vienna & AT & 318000 & free & own & private & 1 & 0 & 0 \\
\hline & Malaga & ES & 298401 & law & external & state & 0 & 1 & 0 \\
\hline & Klaipeda & LT & 294954 & law & external & state & 0 & 1 & 0 \\
\hline & Trieste & IT & 281689 & law & external & state & 0 & 1 & 0 \\
\hline & Salerno & IT & 274940 & law & external & state & 0 & 1 & 0 \\
\hline & Thessaloniki & EL & 273282 & law & own & state & 0 & 1 & 0 \\
\hline & Tarragona & ES & 255407 & law & external & state & 0 & 1 & 0 \\
\hline & Riga & $\mathrm{LV}$ & 182980 & law & external & state & 0 & 1 & 0 \\
\hline & Savona & IT & 220000 & law & external & state & 0 & 1 & 0 \\
\hline
\end{tabular}




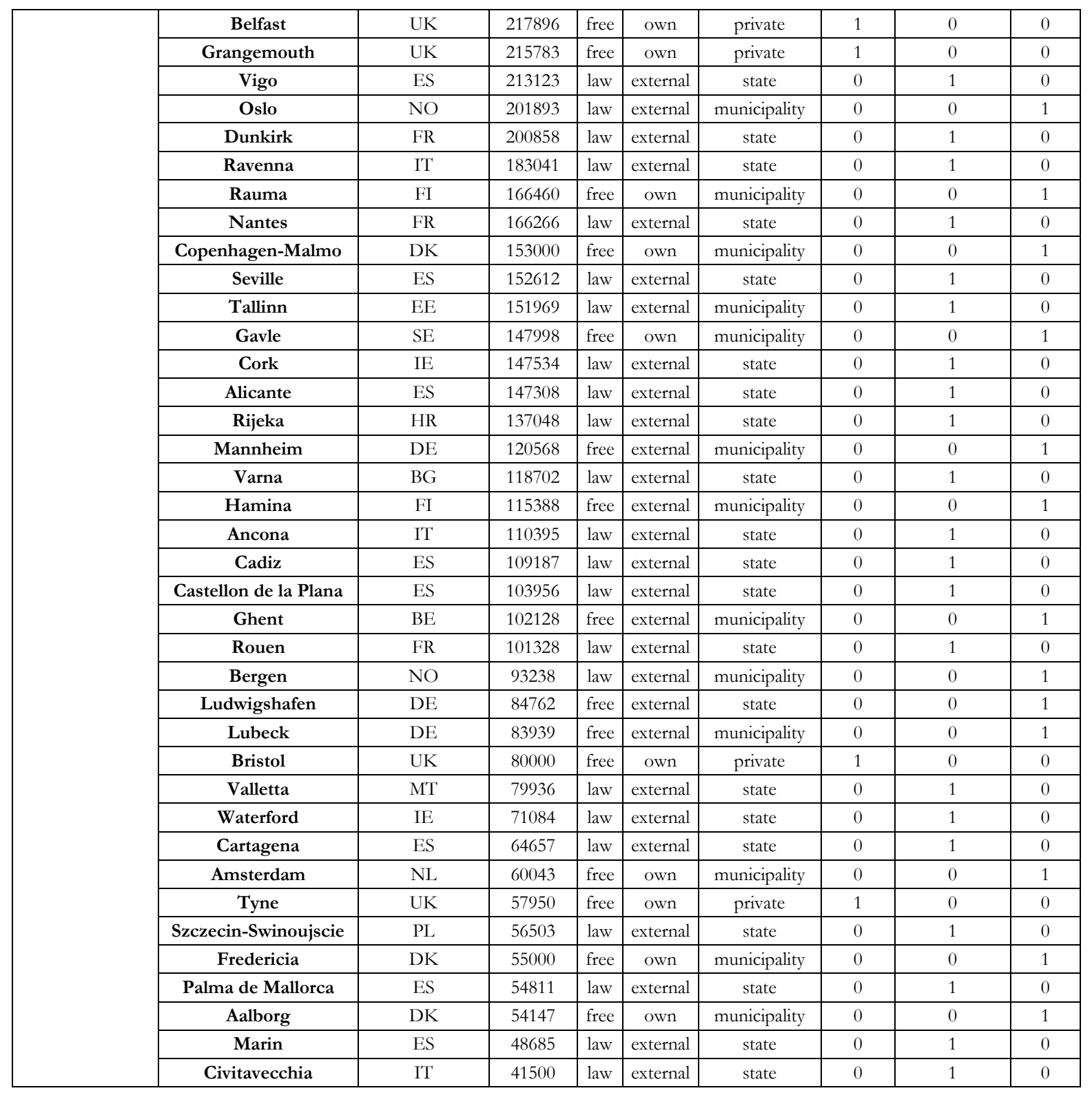

